\title{
DICTIONARY OF LABOUR BIOGRAPHY
}

VOLUME XI 



\title{
DICTIONARY \\ OF \\ LABOUR BIOGRAPHY
}

\author{
Volume XI
}

Edited by

KEITH GILDART

Research Fellow, Department of Politics, University of York

\section{DAVID HOWELL}

Professor of Politics, University of York

and

NEVILLE KIRK

Professor of Labour and Social History, Manchester Metropolitan University 




(c) Keith Gildart, David Howell and Neville Kirk 2003

Softcover reprint of the hardcover 1st edition 2003 978-0-333-96872-7

All rights reserved. No reproduction, copy or transmission of this publication may be made without written permission.

No paragraph of this publication may be reproduced, copied or transmitted save with written permission or in accordance with the provisions of the Copyright, Designs and Patents Act 1988, or under the terms of any licence permitting limited copying issued by the Copyright Licensing Agency, 90 Tottenham Court Road, London W1T 4LP.

Any person who does any unauthorised act in relation to this publication may be liable to criminal prosecution and civil claims for damages.

The authors have asserted their rights to be identified as the authors of this work in accordance with the Copyright, Designs and Patents Act 1988.

First published 2003 by

PALGRAVE MACMILLAN

Houndmills, Basingstoke, Hampshire RG21 6XS and

175 Fifth Avenue, New York, NY 10010

Companies and representatives throughout the world

PALGRAVE MACMILLAN is the global academic imprint of the Palgrave Macmillan division of St. Martin's Press, LLC and of Palgrave Macmillan Ltd. Macmillan is a registered trademark in the United States, United Kingdom and other countries. Palgrave is a registered trademark in the European Union and other countries.

ISBN 978-1-349-42872-4

ISBN 978-0-230-50018-1 (eBook)

DOI 10.1057/9780230500181

This book is printed on paper suitable for recycling and made from fully managed and sustained forest sources.

A catalogue record for this book is available from the British Library.

Library of Congress Cataloging-in-Publication Data

A catalogue record for this book is available from the Library of Congress

$\begin{array}{llllllllll}10 & 9 & 8 & 7 & 6 & 5 & 4 & 3 & 2 & 1\end{array}$

$\begin{array}{llllllllll}12 & 11 & 10 & 09 & 08 & 07 & 06 & 05 & 04 & 03\end{array}$ 


\section{Contents}

ACKNOWLEDGEMENTS

vii

Notes to READERS

ix

LIST OF CONTRIBUTORS

xi

LIST OF BIBLIOGRAPHIES AND

SPECIAL Notes

xiii

BIOGRAPHIES

XV

CONSOLIDATED LisT OF

NAMES IN Volumes I-XI

GENERAL InDEX

307 



\section{Acknowledgements}

The research for this volume was funded by a generous grant from the Arts and Humanities Research Board (AHRB). This funding was indispensable. We are immensely grateful to all our contributors, not just for their entries but also for the tolerance with which they have responded to our suggestions.

This project has drawn on a wide range of library resources. Three institutions merit special attention: the Manchester Central Reference Library, the Modern Records Centre at the University of Warwick, and the Archive at the National Museum of Labour History, Manchester. In each case the richness of the holdings has been complemented by the helpfulness of the staff.

One concern of the editors is to highlight the diversity of national and ethnic identities within the labour movements of the British Isles. In this context we thank the Northern Ireland Record Office and the Linen Hall Library, both in Belfast, the National Library of Ireland in Dublin, and the Library of University College in Dublin; the National Library of Scotland in Edinburgh, and the Mitchell Library in Glasgow; the National Library of Wales in Aberystwyth, the Record Offices for Flintshire, Denbighshire and Glamorgan in Hawarden, Ruthin and Cardiff respectively, and the Newport Public Library.

Beyond the British Isles we thank the Russian State Archive for Socio-Political History and the Marx-Engels Institute, both in Moscow, the International Institute for Social History in Amsterdam, the Library of Columbia University in New York, and Yale University Library.

Amongst the many institutions that were indispensable to the project we are grateful to the Public Record Office in Kew, the British Library - including that most valuable repository of obscure facts, the Newspaper Library in Colindale - and the Working Class Movement Library in Salford. We also thank the TUC's Congress House, the Co-operative College in Loughborough, the Co-operative Library in Manchester, the Bishopsgate Institute Library in London, Chetham's Library in Manchester, the India Office Library, the Social Credit Secretariat, the National Union of Mineworkers in Wrexham, and Newark Advertiser office.

University libraries have provided essential help with primary materials and elusive secondary sources. We gratefully acknowledge the assistance of the Bodleian Library and Nuffield College in Oxford, the British Library of Political and Economic Science at the London School of Economics, the Brynmor Jones Library at the University of Hull, the John Rylands University Library at the University of Manchester and the Morrell Library at the University of York, together with the libraries at Ruskin College and the Universities of London, Cambridge, Nottingham, Staffordshire and Sussex.

Record Offices and public libraries provided vital information. The English Record Offices consulted included Derby, Whitehaven, Carlisle and Nottingham, together with the Leeds City Archive. Public libraries that provided information for this volume included the Salford Local Studies Library and the Boston, Doncaster, Newark and Spalding Libraries.

Essential details for all the entries have been obtained from the Family Records Centre in Finsbury, the General Register Office for Scotland in Edinburgh, and the Probate Office in Manchester.

The research inevitably raised many obscure questions, and Mark Curthoys of the Oxford Dictionary of National Biography offered much wise advice on where to look for answers. His support and that of our contributors has shown that despite all claims to the contrary, the ideal of a community of scholars is not anachronistic.

John Saville has been a model former editor, always encouraging and a source of wisdom. We owe him a great deal. 



\section{Notes to Readers}

1. Place names are usually quoted according to contemporary usage in the period covered in each entry.

2. Where the amount of a will, estate or effects is quoted it is normally that given in The Times, in the records at Somerset House in London or at the Scottish Record Office in Edinburgh. For dates before 1860 the source is usually the Public Record Office.

3. Under the heading Sources, personal information relates to details obtained from relatives, friends or colleagues of the individual in question; biographical information refers to other sources.

4. The place of publication in the bibliographical sources is London unless otherwise stated.

5. The See also sections that follow some biographical entries include names marked with a dagger - these refer to biographies published in Volumes I-X of the Dictionary of Labour Biography; those with no marking are included in the present volume.

6. A consolidated list of the entries in Volumes I-XI can be found at the end of this volume, before the general index. 



\section{List of Contributors}

Professor Owen Ashton

Terence Bowman

Dr Amanda Capern

Dr Stephen Catterall

Dr Gisela Chan Man Fong

Dr Malcolm Chase

Dr Gidon Cohen

Dr Nina Fishman

Dr Andrew Flinn

Dr June Hannam

Ursula Masson

John McIlroy

Dr Kevin Morgan

Lowri Newman

Dr Emmet O'Connor

Dr Paul Pickering

Archie Potts

Dr Miles Taylor

Richard Temple

Dr Andrew Thorpe

Dr Richard Whiting
School of Humanities, Staffordshire University

Mourne Observer, Newcastle, County Down

Department of History, University of Hull

University of Huddersfield

Rock Forest, Quebec, Canada

Department of Continuing Education, University of Leeds

Department of Politics, University of Northumbria

School of Social Sciences, University of Westminster

School of Library, Archive, and Information Studies, University College London

School of History, University of West England, Bristol

School of Humanities, University of Glamorgan

Department of Sociology, University of Manchester

Department of Government, University of Manchester

School of Humanities, University of Glamorgan

School of History, University of Ulster

Australian National University, Canberra

Gosforth, Newcastle-upon-Tyne

University of Southamton

Modern Records Centre, University of Warwick

Department of History, University of Exeter

Department of History, University of Leeds 



\title{
List of Bibliographies and Special Notes
}

\section{Bibliographies}

The subject bibliographies attached to certain entries are the responsibility of the editors. The entries under which they will be found in Volumes I-VI are as follows:

\section{British Labour Party}

1900-13

1914-31

Chartism to 1840

Christian Socialism, 1848-54

Cooperation

Agricultural cooperation

Cooperative education

Cooperative Party

Cooperative production

Cooperative Union

Cooperative wholesaling

Copartnership

International Cooperative

Alliance

Irish cooperation

Retail cooperation

Nineteenth century

1900-45

1945-70

Scottish cooperation

Guild socialism

Mining trade unionism

1850-79

1880-99

1900-14

1915-26

1927-44

Scottish mining trade unionism

Welsh mining trade unionism

New model unionism

New unionism, 1889-93

\author{
LANSBURY, George \\ HENDERSON, Arthur \\ LOVETT, William \\ LUDLOW, John Malcolm Forbes \\ PLUNKETT, Sir Horace Curzon \\ HALL, Fred \\ ALEXANDER, Albert Victor \\ JONES, Benjamin \\ HAYWARD, Fred \\ REDFERN, Percy \\ GREENING, Edward Owen \\ MAY, Henry John \\ GALLAGHER, Patrick \\ HOLYOAKE, George Jacob \\ BROWN, William Henry \\ BONNER, Arnold \\ MAXWELL, William \\ SPARKES, Malcolm \\ MACDONALD, Alexander \\ PICKARD, Benjamin \\ ASHTON, Thomas \\ COOK, Arthur James \\ LEE, Peter \\ SMILLIE, Robert \\ ABRAHAM, William (Mabon) \\ ALLAN, William \\ TILLETT, Benjamin (Ben)
}




\section{Special Notes in Volume $\mathbf{V}$}

Parliamentary Recruiting Committee and Joint Labour Recruiting Committee in the First World War, see BOWERMAN, Charles William

1917 Club, see HAMILTON, Mary Agnes

Mosley Industrial Commission, see STEADMAN, William (Will) Charles

\section{Special Notes in Volume VI}

Woman's Industrial Independence (1848, reprinted), see BARMBY, Catherine Isabella

Boggart Hole Clough and Free Speech, see BROCKLEHURST, Frederick

Ca'canny, see DAVIS, William John

\section{Special Notes in Volume VII}

League Against Imperialism, 1927-37, see Bridgeman, Reginald Francis Orlando

Gateshead Progressive Players, 1920-80, see DODDS, Ruth

Meerut Trial, 1929-33, see GOSSIP, Alexander (Alex)

Execution of Francisco Ferrer and the Labour Movement, see WARD, George Herbert Bridges

\section{Special Notes in Volume VIII}

Guild of St Matthew, see HANCOCK, Thomas

Church Socialist League, see MOLL, William Edmund

Twentieth Century Press, see QUELCH, Henry (Harry)

British Labour Delegation to Russia, 1920, see TURNER, Sir Ben

\section{Special Notes in Volume IX}

Aid for Spain Movement in Britain, 1936-39, see BROWN, Isabel

British Trade Union Delegation to Russia, 1924, I, Official Report, II, The Zinoview Letter, see GRENFELL, Harold

British Joint Labour Delegation to Hungary, Inquiry into the White Terror, May 1920, see JOWETT, Frederick William

\section{Special Notes in Volume $\mathbf{X}$}

Churches of Christ as a Labour Sect, see TAYLOR, John Thomas

Further Notes, see HANNINGTON, Walter

Further Notes, see CONNELL, Jim

Special Notes in Volume XI

Laski Libel Trial, see HASTINGS, Patrick, Sir

Labour Parliament, 1853-4, see JONES, Ernest

Independent Socialist Party, see SANDHAM, Elijah 